\title{
Is it possible to decolonize the concept of cultural anthropophagy?"
}

María Iñigo Clavo is a researcher, curator and professor of Open Universify of Catalonia, with a PhD in Fine Arts from the Universidad Complutense in Madrid, Spain.

ORCID: 0000-0001-7086-1218
Abstract The article analyzes the origins of the Anthropophagy category that arises at the beginning of the 20th century based on Oswald de Andrade's elaboration and asks about the possibility or impossibility of its re-elaboration in the contemporary curatorial context in connection with the category of decolonization. August 12, 2016.

Keywords Cultural anthropophagy, Decolonial, Curatorial criticism, Latin America. 


\section{É possível decolonizar o conceito de antropofagia cultural?}

Resumo $\mathrm{O}$ artigo analisa as origens da categoria Antropofagia, que surge no início do século XX, a partir da elaboração de Oswald de Andrade e a possibilidade ou impossibilidade de sua reelaboração no contexto curatorial contemporâneo em conexão com outra categoria, a decolonização. Agosto 12, 2016

Palavras chave Antropofagia cultural, Decolonial, Crítica curatorial, América Latina.

¿Es posible descolonizar el concepto de antropofagia cultural?

Resumen El artículo analiza los orígenes de la categoría de Antropofagia que surge a principios del siglo XX basada en la elaboración de Oswald de Andrade y la posibilidad o imposibilidad de su reelaboración en el contexto curatorial contemporáneo en relación con otra categoría, la decolonización. Agosto 12, 2016.

Palabras clave Antropofagia cultural, Decolonial, Crítica curatorial, América Latina. 
Is it possible to decolonize the concept of cultural anthropophagy? I think that this is a key question, because the concepts of mestizaje1 and cultural anthropophagy have in common their conservation of both the virtues and defaults with which they were born at the beginning of the 20th century.

If exhibitions such as Mostra do Redescobrimento divided objects in discrete spaces dedicated to indigenous, Afro-Brazilian, baroque, folk, modern and contemporary art, in recent years, new exhibitions have displayed these objects face to face. This tactic has resulted in challenging shows that, by necessity, demonstrate the nature of relationships between production, spheres of knowledge, politics, and culture. Histórias Mestiças and the 34 Panorama de Arte Brasileira mixed objects from these different fields, and MAR in Rio de Janeiro has used this methodology for its exhibitions since its inception.

The concept of cultural anthropophagy supposed a movement of decolonization of 19th-century European national ideology. Theorists such as Silvio Romero, Euclides da Cunha, and Nina Rodríguez tried desperately to adjust Brazilian reality to the patrons of European Modernity, and the contradictions were painful and impossible to hide. It was easier to blame the blacks, indigenous people, and/or the tropical climate for the country's problems. The concept of anthropophagy in the 1920s acknowledged Brazil's specificities and created new paradigms of self-definition differentiated from the European parameters. It was created as an expression of national identity accepting and celebrating its postcolonial character, including (at the end!) the country's indigenous and Afro descent.

So, it's true, one cannot deny the fact that the notion of anthropophagy has generated productive analyses for many disciplines, including literature, psychoanalysis, art, theatre, music, and political theory, through the 20th century and into the present. And in the 1960s, anthropophagy was crucial in liberating artists from leftist debates that demanded of Latin American art and cultural production an impossible purity impervious to foreign influence.

Once one acknowledges this, I would like to ask, what has been the place of indigenous and Afro-Brazilian people in these powerful national rhetorics? To answer, we would need to turn our gaze away from the imperial colonial power relationships between countries, stop accusing each other of Eurocentrism, and analyze and interrogate Brazil's internal colonialism and our complicity with it. 
Then we would realize that the idea of indigeniety has been used as inspiration for intellectual production, frequently linked to national images of Brazilianness, and/or has been an object of study in the long tradition of anthropology in Brazil. But contact with the reality of the social and political communities has been really poor. Antonio Riséiro2has shown how literary texts in Brazil, often inspired by African or indigenous texts, do not really take their grammatical structures and creative methods seriously, failing to truly integrate them into Brazil's textual heritage. Oswald de Andrade made use of European ethnographic literature to elaborate his idea of the indigenous, and "didn't care about contemporary 'Indians' that shoot arrows at Mato Grosso and Goias...even though the Kaigang were quite close by, right there, to the west of São Paulo."

From this vantage point we can use the postcolonial perspective to shed light on how, in de Andrade's Manifesto Antropófago, we can see the strategy involving the incorporation of the "other" that would be substituted by its representations. In this last case, "representation works as a substitute for the active presence-naming it is equivalent to not knowing it"3. Images are a substitute for presence, and in this sense the concept of cultural anthropophagy is absolutely colonial. These problems have been inherited by exhibitions of contemporary art about history such as the 24th São Paulo Bienal of Anthropophagy or Histórias Mestiças. The latter used objects of ethnography or material culture. What the exhibitions of these collectives are not showing are a real political presence, an agency that is not just resisting, but also contributing to the independence process, to the insurgencies, to the history of the Republics, to the end of dictatorship, and to a Brazilian and Amazonic citizenship. They can relate something other than a history of victims and propose new models to inhabit politically.

The anthropologist Roberto da Matta4said that in a hierarchical society such as Brazil's, it is not being different that's a crime, but rather failing to occupy the place allotted to you. This is my feeling about these exhibitions, that these objects occupy the place allotted to them by the Brazilian intelligentsia without disturbing the hegemonic national narrative. In this sense, we could go as far as saying that rather than a history of these collectives, these exhibitions could be seen as examples of how to narrate the history of a national elite and its school of thought regarding alterity.5

In conclusion, I will point to the second barrier that I think blocks a critical rereading of Brazilian history. The persistence of colonial structures in our time is supported by the continued defence and celebration of the National. As postcolonial theorists have insisted, the Nation is an important accomplice of colonialism, because the models of Nation for Latin America were (north) European and colonial in nature. Without access to alternative models of Nation, the indigenous continued to occupy the same place after the independences as they had before. Thus, to overcome Brazil's internal colonialism would necessitate an acknowledgment of the ways in which the national discourses have hidden and fostered coloniality and have concealed resistant collectives in the past and in the present. 
Exhibitions focused on the celebration of Nation, demonstrating again and again its foundational myths, therefore contradict a real critical review of colonial power relationships of the past and present that a truly postcolonial perspective could offer. In the last three years we have witnessed for the first time the emergence of Afro-Brazilian collectives reclaiming their visibility in the art circuit. Is it possible to go beyond a multiculturalism model based on (supposed) inclusion? How can we offer strategies that don't use alterity in Brazil as content or a theme, but propose a challenge of its structures, forces that could change the forms? Is it possible to decolonize the nation?

1 Silvia Rivera Cusicanqui asked, "is it possible to decolonize mestizaje?", Boaventura de Sousa Santos in his side formulated a similar question, is it possible to decolonize marxism?

2 Risério, Antonio. Textos e tribos: Poéticas Extraocidentais nos trópicos brasileiros. Rio de Janeiro, Imago, 1993. p.107

3 Barthes describes two ways of incorporating the Other: "Inoculation, in which the other is absorbed only to the extent necessary to make it innocuous; and incorporation, where the other becomes incorporeal by means of its representation." quoted in Foster, Hal, Recodings: Art, Spectacle, Cultural Politics. New York, The New Press 1998.

4 Da Matta, Roberto. Relativizando: uma Introdução à Antropologia Social. Rio de Janeiro, Rocco, 1987. p. 79

5 Some of the questions posted here are explained further in a text entitled, Is Brazil a postcolonial country?, focused on the Historias Mestizas exhibition. This text will be published by Paragrana magazine at Freie University of Berlin this fall as a result of the conference $F(r)$ ictions of Arts organized by Freie University and Goldsmiths University. 